\title{
INTENSITAS DAN LAJU INFEKSI PENYAKIT KARAT DAUN Uromyces phaseoli PADA TANAMAN KACANG MERAH
}

\author{
INTENSITY AND INFECTION RATE OF RUST LEAF Uromyces phaseoli ON RED BEAN
}

\author{
Guntur S.J. Manengkey dan Emmy Senewe*) \\ *Dosen Jurusan Hama dan Penyakit Tumbuhan, Fakultas Pertanian Unsrat Manado- 95115
}

\begin{abstract}
Rust leaf on red bean is major desease in the area of Tonsewer, Toure dan Tumaratas village. The aim of the study was to determine the intensity and infection rate of rust disease on red bean at Tonsewer, Toure and Tumaratas village, The method used was survey by drawing a diagonal line at four points and one point in the center of each farm. Hence, there were five points that were used for sampling area for calculating the intensity and the infection rate caused by leaf rust Uromyces phaseoli. The result showed that red bean farm in the village of Tonsewer, Toure and Tumaratas had been infected by rust disease caused by the fungus Uromyces phaseoli . The average of attacking intensity was $62.29 \%$ in Tonsewer. Whereas, Toure and Tumaratas were $61.71 \%$ and 62.29 respectively. The average of infection rate was 0.239 per unit per day in the Tonsewe. While in the Toure and Tumaratas were 0.189 and 0.208 per unit per day respectively .
\end{abstract}

Keyword : Intensity and infection rate, Red Bean

\section{ABSTRAK}

Intensitas dan laju infeksi penyakit karat daun Uromyces phaseoli pada tanaman kacang merah, dengan tujuan penelitian yaitu untuk mengetahui intensitas dan laju infeksi penyakit karat pada kacang merah di Desa Tonsewer, Toure Kecamatan Tompaso dan Tumaratas Kecamatan Langowan Barat. Metode yang digunakan adalah survei dengan cara menarik satu garis diagonal pada empat titik dan satu titik di tengah pada masing-masing kebun sehingga terdapat lima titik yang akan dihitung intensitas dan laju infeksi penyakit karat daun Uromyces phaseoli. Hasil penelitian menunjukkan bahwa pertanaman kacang merah di Desa Tonsewer, Toure dan Tumaratas telah terserang penyakit karat yang disebabkan oleh Jamur Uromyces phaseoli dengan intensitas serangan sebesar rata-rata 62,29\% di Desa Tonsewer; 61,71 \% di Desa Toure dan 62,29 \% di Desa Tumaratas, dan laju infeksi rata-rata 0,239 per unit per hari di Desa Tonsewer; 0,189 per unit per hari di Desa Toure ; 0,208 per unit per hari di Desa Tumaratas

Kata kunci : Intensitas dan tingkat infeksi, kacang merah

Eugenia Volume 17 No. 3 Desember 2011 


\section{PENDAHULUAN}

Kacang buncis (Phaseolus vulgaris L.) berasal dari Amerika, tanaman buncis tipe tegak atau kacang jogo adalah tanaman asli lembah Tahuacan-Meksiko. Penyebaran tanaman dari Amerika ke Eropa pada abad ke-16. Pusat penyebaran dimulai dari Inggris ( 1594 ), kemudian ke negara-negara Eropa, Afrika, sampai ke Indonesia, (Anonim, 2004).

Tanaman ini memiliki banyak jenis tetapi pada garis besarnya dapat dibagi menjadi dua golongan yaitu yang membelit dan tidak membelit. Golongan membelit disebut buncis, kacang lompeh (rompes), berbiji ungu, putih dan hitam, sedangkan golongan kacang buncis yang tidak membelit disebut kacang jogo salah satunya adalah kacang merah atau kacang jogo brenebon. Tanaman ini pendek, tingginya $\pm 30 \mathrm{~cm}$, bijinya berwarna merah atau merah berbintik bintik putih (Sunarvono, 1981).

Permintaan terhadap produk ini diperkirakan akan terus meningkat seiring dengan pertambahan jumlah penduduk. Mengacu pada Pola Pangan Harapan (PPH) tahun 2000, konsumsi ratarata penduduk Indonesia adalah sebesar 35,88 g/kapita/hari (Fachruddin, 2000).

Tanaman memiliki manfaat yang sangat banyak, bukan hanya untuk memenuhi kepentingan konsumsi semata, tetapi juga merupakan bahan pangan yang benilai gizi tinggi. Biji kacang- kacangan mengandung protein yang cukup tinggi dan vitamin B. Bagian terpenting dari tanaman kacang yang dimanfaatkan sebagai bahan pangan adalah biji (Fachruddin, 2000).

Tanaman kacang-kacangan dapat meningkatkan kesuburan tanah, karena akar-akarnya bersimbiosis dengan bakteri rhizobium yang mampu mengikat nitrogen bebas dari udara. Nitrogen bebas yang diikat tersebut, kemudian disimpan dalam bentuk bintil-bintil akar (nodula). Bintil-bintil akar yang mengandung nitrogen tersebut sangat berfungsi untuk memperbaiki kesuburan tanah, sehingga tanah yang sudah berkurang kesuburannya dapat diperbaiki dengan ditanami kacang-kacangan. Limbah tanaman kacang-kacangan yang berupa brangkasan dapat dimanfaatkan sebagai pupuk organik dapat dijadikan tanaman penutup tanah (Fachruddin, 2000).

Dalam usaha budidaya kacang merah, tidak luput dari gangguan hama maupun patogen penyebab penyakit. Salah satu patogen yang menginfeksi kacang merah adalah jamur Uromyces phaseoli penyebab penyakit karat. Patogen ini penting karena mempengaruhi kualitas dan kuantitas. Kerusakan yang timbul pada daun yaitu bintil-bintil kecil berwarna coklat yang agak menonjol dapat menggangu proses fotosintesis, sehingga tanaman kekurangan suplai makanan dan pembentukan polong dapat terganggu. Biasanya penyakit muncul jika faktor luar (lingkungan) mendukung. Faktor luar memberikan pengaruh yang paling kuat terhadap patogen, pertama mendukung terjadinya infeksi, kedua yaitu dengan mempengaruhi tumbuhan inang yaitu kerentanan tumbuhan terhadap patogen (Semangun, 2001).

Menurut Kerr (1980) dalam Sudarma (1989) kelembaban adalah faktor cuaca yang sangat penting mempengaruhi ledakan penyakit. Kelembaban dapat dinyatakan sebagai curah hujan, kelembaban relatif dan lama daun basah. Pada umumnya perkecambahan spora dan perkembangan pertama dan parasit berhubungan erat dengan kelembaban (Semangun, 2001).

Meskipun suhu mempunyai pengaruh, namun secara umum pengaruhnya tidak sebanding dengan kelembaban. Jika kelembaban mempunyai pengaruh yang menentukan maka suhu hanya mempunyai pengaruh membedakan yaitu menghambat atau mempercepat. Suhu dapat mempengaruhi banyaknya spora yang dapat berkecambah. Pada umumnya suhu minimum untuk perkecambahan spora adalah $1-3^{\circ} \mathrm{C}$ dan suhu maksimumnya adalah $30-36^{\circ} \mathrm{C}$. Suhu optimum tergantung jenisnya. Pengaruh suhu terhadap penyakit melalui tumbuhan inang lebih sukar diketahui dengan pasti. Jamur penyebab penyakit dapat verkembang lebih cepat dalam suhu yang tinggi. Pada banyak contoh mengenai pengaruh suhu terhadap penyakit belum diketahui dengan jelas bagaimanakah mekanisme pengaruh itu (Semangun, 2001).

Cahaya dapat berpengaruh secara tidak langsung maupun langsung. Secara tidak langsung cahaya dapat mempengaruhi kelembaban dan se- 
cara langsung cahaya berpengaruh terhadap patogen yang masih berada di luar badan tumbuhan.

Pada jamur tertentu misalnya uredinales perkecambahan spora dihambat oleh sinar. Spora yang basah lebih peka terhadap hambatan oleh cahaya, juga hal ini berlaku untuk sinar ultra violet. Spora yang sudah mulai berkecambah juga lebih peka terhadap sinar. Sinar menyebabkan pembuluh kecambah membelok menjauhi sumber cahaya (Semangun, 2001).

Penyakit karat merupakan penyakit yang sering terdapat pada pertanaman kacang merah di Tonsewer, Toure dan Tumaratas. Oleh karena itu perlu diketahui perkembangan penyakit karat (Uromyces phaseoli) pada kacang merah.

Penelitian bertujuan untuk mengetahui laju infeksi dan tingkat serangan penyakit karat daun pada kacang merah di Desa Tonsewer, Toure dan Tumaratas.

\section{METODE PENELITIAN}

Penelitian ini dilakukan di lapangan dan laboratorium. Di lapangan dilaksanakan di tiga desa yaitu Desa Tonsewer, Toure dan Tumaratas. Di laboratorium menyangkut penentuan patogen dan perhitungan spora dilaksanakan di Laboratorium Mikrobiologi dan Penyakit Tumbuhan Fakultas Pertanian Universitas Sam Ratulangi Manado. Penelitian berlangsung selama dua bulan.

Bahan yang digunakan dalam penelitian ini terdiri vaselin putih, lactophenol cotton blue dan tanaman kacang merah yang terinfeksi penyakit karat. Peralatan yang digunakan dalam penelitian ini adalah gelas benda, alat pengukur suhu dan kelembaban (bola kering dan bola basah), mikroskop, kamera, hand counter dan alat tulis menulis.

\section{Metode Penelitian}

Metode yang digunakan dalam penelitian ini adalah metode survei dengan pengamatan langsung di tiga lokasi pertanaman kacang merah yaitu Tonsewer, Toure dan Tumaratas. Petak pengamatan diambil secara diagonal pada bagian sudut dan tengah petak yang berukuran $1 \times 1$ meter sehingga jumlah petak dalam satu lokasi ada lima. Hal-hal yang diamati dalam penelitian ini adalah gejala pe- nyakit di lapangan, intensitas serangan, laju infeksi, dan bentuk spora $U$. phaseoli.

\section{Pelaksanaan Penelitian}

Penelitian di lapangan dilakukan untuk mengetahui gejala penyakit, laju infeksi penyakit, intensitas penyakit dan penangkapan spora di udara sedangkan penelitian laboratorium dilakukan untuk mengetahui morfologi penyebab penyakit dan perhitungan spora yang tertangkap. Penelitian dilakukan dengan mengamati bagian tanaman yang terinfeksi selama 7 hari untuk menghitung laju infeksi dan intensitas serangan. Penangkapan spora dilakukan pada ketiga lokasi penelitian. Penelitian dilaksanakan secara simpel random sampling yaitu pengambilan sampel populasi dilakukan secara acak tanpa memperhatikan strata yang ada dalam populasi.

\section{Pengamatan Laju Infeksi}

Pada perhitungan laju infeksi penyakit karat pada kacang merah, pengamatan dilakukan pada tanaman yang berumur 1 bulan. Petak sampel diambil secara diagonal pada bagian sudut dan tengah petak yang berukuran $1 \times 1 \mathrm{~m}$ sehingga jumlah petak dalam satu lokasi ada lima. Jumlah daun yang diamati pada tiap petak sampel adalah 15 daun sehingga total daun yang diamati dalam satu lahan adalah 75 daun dan pengamatan dilakukan selama 7 hari. Perhitungan laju infeksi menggunakan rumus epidemiologi Van der plank 1963 dalam Oka, 1992;

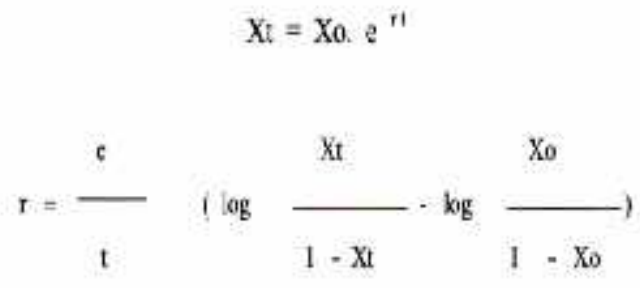

diresa.

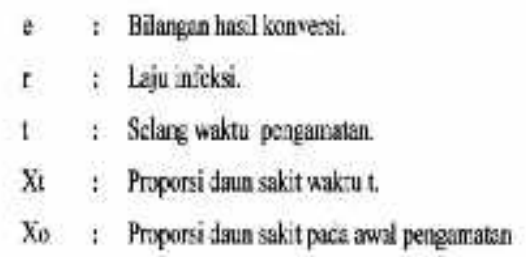




\section{Intensitas Penyakit}

Pengamatan dilakukan pada daun kacang merah pada tanaman yang sama pada pengamatan laju infeksi dengan skoring tersebut dibawah ini.

\begin{tabular}{cl} 
Tingkat Gejala & \multicolumn{1}{c}{ Gambaran Infeksi } \\
0 & Tidak ada infeksi pada daun \\
1 & Luas daun terinfeksi $0-10 \%$ \\
2 & Luas daun terinfeksi $>10-25 \%$ \\
3 & Luas daun terinfeksi $>25-45 \%$ \\
4 & Luas daun terinfeksi $>45-75 \%$ \\
5 & Luas daun terinfeksi $>75 \%$
\end{tabular}

Sumber : Sugiharso dalam Sudarma 1981

Hasil pengamatan yang diperoleh selanjutnya dimasukkan ke dalam rumus intensitas penyakit yang dibuat oleh Towsend dan Hueberger yang disempurnakan oleh Kesper 1965 dalam Ismed, 1993.

Penelitian di laboratorium dilakukan untuk mengetahui morfologi penyebab penyakit karat pada tanaman kacang merah. Pengamatan dilakukan dengan mengamati bagian daun tanaman yang terinfeksi dan melihat bentuk morfologi jamur penyebab penyakit karat serta menghitung jumlah spora yang tertangkap dengan bantuan mikroskop.

\section{Analisis Data}

Setelah semua data terkumpul, selanjutnya dianalisis dengan menggunakan analisis Path sehingga dapat diketahui hubungan antara masingmasing variabel bebas dan tidak bebas.

\section{HASIL DAN PEMBAHASAN}

\section{Gejala Penyakit Karat Kacang Merah}

Hasil penelitian menunjukkan pada lokasi pertanaman kacang merah sudah terdapat adanya serangan patogen penyebab penyakit karat. Gejala pada permukaan daun terdapat bercak berbentuk bintil-bintil kecil agak menonjol berwama coklat. Pada umumnya bintil-bintil tersebut dikelilingi oleh klorosis, walaupun ada juga yang hanya berupa bintil coklat.

Menurut Semangun (1990) pada jenis yang rentan bercak dapat membesar dengan garis tengah sekitar $2 \mathrm{~mm}$ dan mempunyai massa spora berwama coklat berupa tepung. Bercak dapat mempunyai halo berwama kekuningan dan sering bercak dikelilingi oleh satu cincin coklat tambahan. Massa yang berwama coklat tadi dapat menjadi coklat tua gelap yang disebabkan karena perkembangan jamur penyebab penyakitnya.

Hasil pengamatan mengenai bentuk urediospora dari $U$. phaseoli berbentuk bulat atau jorong dan berwama kuning emas. Urediospora akan berkecambah membentuk hifa infektif dengan sel berinti dua, dan dalam waktu beberapa hari sudah dapat menghasilkan urediospora baru.

\section{Laju Infeksi Penyakit Karat}

Hasil pengamatan laju infeksi penyakit pada ketiga lokasi penelitian dapat dilihat pada Tabel 1. Pada tabel tersebut terlihat bahwa rata-rata laju infeksi penyakit karat tidak berbeda nyata antara ketiga desa, ini berarti penyakit karat telah bersifat endemik pada daerah tersebut. Hasil pengamatan terhadap 225 sampel daun tanaman tampak berfluktuasi. Ini mungkin disebabkan karena keadaan lingkungan pada saat pengamatan terutama yang berperan adalah suhu dan kelembaban, akan tetapi dalam proses infeksi tidak selalu mendukung perkembangan penyakit sehingga terjadi fluktuasi infeksi dari waktu ke waktu.

Nilai rata-rata laju infeksi kurang dari 0,5 per unit per hari, ini mungkin disebabkan karena patogen tidak terlalu agresif, varietas inang tahan dan faktor lingkungan tidak terlalu mendukung perkembangan patogen. Menurut Van der Plank (1963) dalam (Sudarma 1989) nilai laju infeksi dapat diartikan apakah patogen agresif, varietas rentan atau tahan dan apakah lingkungan mendukung atau tidak untuk perkembangan penyakit. Apabila nilai r lebih besar dari 0,5 unit per hari, berarti patogen agresif, varietas inang rentan dan cuaca mendukung begitu juga sebaliknya.

Tingkat serangan pada awal pengamatan dengan laju infeksi 0.235 per unit per hari dan akhir pengamatan 0.171 per unit per hari. Pada fase pertama (hari pertama dan kedua) laju infeksi cukup tinggi yaitu sebesar 0,235 per unit per hari kemudian mengalami peningkatan menjadi 0,261 per unit per hari. 
Tabel 1. Laju Infeksi Penyakit Karat Tanaman Kacang Merah

(Table 1.Disease Infection Rate of Rust Disease on Red Bean Plantation)

\begin{tabular}{clrrrrrrr}
\hline \multirow{2}{*}{ No } & Lokasi & \multicolumn{8}{c}{ Laju Infeksi } \\
\cline { 3 - 8 } & Penelitian & $\mathrm{r}^{1}$ & $\mathrm{r}^{2}$ & $\mathrm{r}^{3}$ & $\mathrm{r}^{4}$ & $\mathrm{r}^{5}$ & $\mathrm{r}^{6}$ & Rerata \\
\hline 1. & Tonsewer & 0,261 & 0,361 & 0,274 & 0,209 & 0,190 & 0,188 & 0,239 \\
2. & Toure & 0,195 & 0,212 & 0,201 & 0,197 & 0,167 & 0,166 & 0,189 \\
3. & Tumaratas & 0,250 & 0,261 & 0,223 & 0,179 & 0,174 & 0,161 & 0,208 \\
\hline
\end{tabular}

Tabel 2. Rata-rata Intensitas Serangan U. phaseoli di Setiap Lokasi Penelitian (Table 2. The Average of Attack Intensities of U. phaseoli in Research Locations)

\begin{tabular}{ccc}
\hline No. & Lokasi Penelitian & Rata-rata (\%) \\
\hline 1 & Tonsewer & 62,29 \\
2 & Toure & 61,71 \\
3 & Tumaratas & 62,29 \\
\hline
\end{tabular}

Hal ini disebabkan karena inokulum yang tersedia cukup banyak, jaringan inang masih cukup banyak untuk diinfeksi dan faktor cuaca mendukung untuk melakukan infeksi. Fase berikutnya laju infeksi mulai menurun disebabkan jaringan inang sehat yang tersedia mulai berkurang karena juga terdapat jamur lain yang menyerang daun dan menyebabkan bercak coklat kekuningan.Laju infeksi paling rendah terlihat pada fase terakhir (hari ke enam dan ke tujuh) yaitu rata-rata sebesar 0.171 per unit per hari.

Tidak ada perbedaan nyata juga disebabkan oleh karena cara pemeliharaan tanaman kacang merah yang hampir sama, bahkan pada lokasi pengamatan belum ada petani yang mengendalikan penyakit secara biologi atau kimia walaupun sebagian besar tanaman telah terserang.

\section{Intensitas Serangan Patogen}

Hasil penelitian mengenai intensitas serangan patogen pada pertanaman kacang merah maka terlihat rata-rata intensitas serangan tidak berbeda nyata, ini terlihat pada tabel 2 . Tabel tersebut menunjukkan bahwa intensitas penyakit karat pada kacang merah di lokasi penelitian tidak menunjukkan perbedaan yang nyata. Intensitas penyakit di Desa Tonsewer dan Desa Tumaratas rata-rata $62,29 \%$ sedangkan di Desa Toure 61,71\%. Hal itu mungkin disebabkan karena penyakit tersebut telah bersifat endemik pada lokasi tersebut. Selain itu kondisi lingkungan yang sama dan cocok untuk perkembangan patogen $U$. phaseoli. Tingginya inten- sitas serangan patogen juga disebabkan karena tanaman tersebut selalu diusahakan secara terus menerus oleh petani di daerah tersebut sehingga patogen dengan mudah dapat menginfeksi.

\section{KESIMPULAN}

Dari hasil penelitian dapat disimpulkan bahwa patogen penyebab penyakit karat telah menginfeksi tanaman kacang merah di Desa Tonsewer, Toure dan Tumaratas. Laju infeksi penyakit pada awal pengamatan adalah 0.235 , dan pada akhir pengamatan adalah 0.181 per unit per hari. Tingginya intensitas serangan penyakit karat disebabkan karena patogen atau penyakit sudah bertahan di areal pertanaman kacang merah

\section{DAFTAR PUSTAKA}

Anonim. 2004. Buncis. Sumber:http:llwww.kpel.or. idlTTGP/komoditilbuncis.com. Pengurusan Buncis. agrolink.moa.my!doalBml eroptechbml pengurusan buncis. htm-5kcached.similar pages.2004. Penyakit Sayuran. http://agrolink. moa.my/pdnet/ kwln/penyakit/pykt/sayur.htm.

Fachruddin, L. 2000. Budidaya Kacang-kacangan. Kanisius. Yogyakarta.

Ismed, S. B. 1993. Kajian Epidemi Penyakit Bercak Daun Kacang Tanah. Tesis. Program Pascasarjana Universitas Gadjah Mada. Yogyakarta. 
Oka. I. N. 1992. Pengantar Epidemiologi Penyakit Tumbuhan. Gadjah Mada University Press. Yogyakarta.

Semangun, H. 1990. Penyakit-Penyakit Tanaman Pangan Di Indonesia. Gadjah Mada University Press. Yogyakarta.2001. 2001. Pengantar IImu Penyakit Tumbuhan. Gadjah Mada University Press. Yogyakarta.
Sudarma, I.M. 1989. Epidemi Penyakit Embun Palsu (Plasmopara viticola) Pada Tanaman Anggur (Vitis yin Vera) Di Tangguwisia, Buleleng. Program Pasca Sarjana Universitas Gadjah Mada. Yogyakarta.

Sunarvono, H. 1981. Pengantar Pengetahuan Dasar Hortikultura II. C.V Sinar Bandung. 
